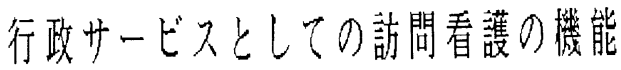

1 埌：訪問看講開始理由別にみた対象の特性

○北川公子、島内節（東京医科曾科大学保健衛生学科）

けまむめ たこ

老人保健法によって市町村や特别区・政令市保健所等を中心とした訪問看缕が開始されて 9 年 を迎えた。この間、病院での訪問看謱が增加し、民間での訪問看護や看識支援センターの硟生、 現在は訪問看缕ステーションの設立が検討されている。従って地域を単位として行政の行なう訪 問看棘の位置づけと評価の必要性は高まっている。今回は東京都内における訪問開始時ニーズと 対象の特徵を明らかにする。

表 1. 訪問看護開始時のニーズ領域

研究它法

鲷查対象は、東京都内の 11 区、 5 市、1 町の合計 17 地区の行政機関で調査時点に訪 問着謱を継続していた全対象 2,380人であ る。资料収集方法は、区の保健所及び区市 町村の衛生所管部で直接訪問看護に従事し ている保健婦、看護婦による各受け持ちの 事例の既存記録と閭き取りによる調查で、 期間は平成 2 年 11 月から 12 月である。調査 票は全対象から回収され、このうち有効回 答は 2,361 人 $(99.2 \%)$ であつた。

研 癸 結 军

1.訪間看缕開始時に把握された主なニース

対象者各人について訪問開始時の主な理由 ニーズ）を 1 つと限定した場合の看護職の判断 を示したものが表 1 である。 I〜Vのニーズ領 域別にみると「介諉面の指導・援助」 $30.4 \%$ 、

「病状の钼察と庭状の看講」 $28.5 \%$ 、「リハビ リテーション」（以下リハビリ） $27.4 \%$ (多く 計 $86.3 \%$ となり、他は $10 \%$ 未涌であった。以下 の分析には表 1 の I Vのニーズ領域を用いた。

\section{2. 対象者の背景}

対象は男性 992 人 $(42.0 \%)$ ，女性 1,369 人 (58.0\%)、全体の平均年部は 76.9 歳、男性 75.1 歳、女性 78.1歳で男性より平均 3 歳高い。 対象者の疾患は、複数回答のうち該当者が 300 人以上に達した 4 疾患（脂卒中、高血啀、心

\begin{tabular}{|c|c|c|c|}
\hline \multicolumn{2}{|c|}{ ニースの領域 } & \multicolumn{2}{|c|}{ [総数 ] $2338(100.0)$} \\
\hline \multirow{2}{*}{ I. 处䈯 } & 䙅瘁の处冝や手当の指道 & $113(4.8)$ & \multirow{2}{*}{$154(6.6)$} \\
\hline & カテーテル等の医撩的处情 & $41(1.8)$ & \\
\hline \multicolumn{2}{|c|}{ II. 病状の観察と症状の看護 } & $666(28.5)$ & $666(28.5)$ \\
\hline \multirow{2}{*}{ III. 介護面の指導 - 援助 } & 介護知識や介諳技術の不足 & $702(30.0)$ & \multirow{2}{*}{$710(30.4)$} \\
\hline & 過剩な介謊 & $8(0.3)$ & \\
\hline \multirow{3}{*}{ IV. リハビリテーション } & 機能訓練 & $484(20.7)$ & \multirow{3}{*}{$642(27.4)$} \\
\hline & 動きたがらない & $106(4.5)$ & \\
\hline & 寝かせきり & $52(2.2)$ & \\
\hline \multicolumn{2}{|c|}{ v. 生活指道（服薬·その他） } & $166(7.1)$ & $166(7.1)$ \\
\hline
\end{tabular}

注） $N, A=23$ 人を除く

表 2.ニーズ領域別にみた疾患の特幑

\begin{tabular}{|c|c|c|c|c|c|}
\hline & 緢数 & $\begin{array}{l}\text { 主疾患 } \\
\text { 他の疾患 }\end{array}$ & $\begin{array}{l}\text { 主疾患 } \\
\text { のみ }\end{array}$ & $\begin{array}{l}\text { 他の疾患 } \\
\text { のみ }\end{array}$ & \\
\hline 䋓 数 & $\begin{array}{l}2233 \\
(100.0)\end{array}$ & $\begin{array}{l}719 \\
(32.2)\end{array}$ & $\begin{array}{l}870 \\
(39.0)\end{array}$ & $\begin{array}{l}644 \\
(28.8)\end{array}$ & \\
\hline I. 処置 & $\begin{array}{c}147 \\
(100.0)\end{array}$ & $\begin{array}{c}56 \\
(38.1)\end{array}$ & $\begin{array}{c}44 \\
(29.9)\end{array}$ & $\begin{array}{c}47 \\
(32.0)\end{array}$ & \\
\hline $\begin{array}{l}\text { II. 病状の観察 } \\
\text { 昰状の看護 }\end{array}$ & $\begin{array}{c}641 \\
(100.0)\end{array}$ & $\begin{array}{l}221 \\
(34.5)\end{array}$ & $\begin{array}{l}199 \\
(31.0)\end{array}$ & $\begin{array}{l}221 \\
(34.5)\end{array}$ & 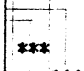 \\
\hline $\begin{array}{l}\text { III. 介绕面の } \\
\text { 指導・援助 }\end{array}$ & $\begin{array}{c}679 \\
(100.0)\end{array}$ & $\begin{array}{l}223 \\
(32.8)\end{array}$ & $\begin{array}{l}294 \\
(43.3)\end{array}$ & $\begin{array}{l}162 \\
(23.9)\end{array}$ & 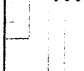 \\
\hline $\begin{array}{l}\text { IV. リハビリ } \\
\text { テーション }\end{array}$ & $\begin{array}{c}609 \\
(100.0)\end{array}$ & $\begin{array}{l}167 \\
(27.4)\end{array}$ & $\begin{array}{l}278 \\
(45.6)\end{array}$ & $\begin{array}{l}164 \\
(27.0)\end{array}$ & \begin{tabular}{|r|}
$* *$ \\
\end{tabular} \\
\hline V. 生活指递 & $\begin{array}{c}157 \\
(100.0)\end{array}$ & $\begin{array}{c}52 \\
(33.1)\end{array}$ & $\begin{array}{c}55 \\
(35.0)\end{array}$ & $\begin{array}{c}50 \\
(31.9)\end{array}$ & \\
\hline
\end{tabular}

注 1） N, B=24人 疾患なし=104人を除く

注 2）主疾患は、莤卒中、高血圧、心疾患、智呆を、他の疾患は それ以外をさす。 $x^{2}$-test $*$ P $<.05 * *<.01 * * *<.001$ 疾患、痴呆）を主疾患、それ以外を他の疾患とし、主疾患十他の疾患、主疾患のみ、他の疾患の みの 3 つの組み合わせを作成した。なお疾患なしは104人であった。表 2 のように処置、及び定状 の钼察と病状の看缕を必要とする群には、主疾患十他の疾患、他の疾患のみがやや多く、介譄面 の指導・援助、リハビリを必要とする群では主疾患のみが多く、各々の群の間に有意差を認めた。 更に他の疾患の内訳をみると、処置を必要とする群では筋骨系疾患、泌尿器疾患が、病状の鼠察 と崖状の看護を必要とする群では難病、呼吸器疾患などが、他の群に比して多い㑯向であった。 
3. 日常生活の介護の程度と介嬑上の困難

ニーズ領域別にみ

$\% 0$

$\begin{array}{llllllllll}10 & 20 & 30 & 40 & 50 & 60 & 70 & 80 & 90 & 100\end{array}$

た日常生活の介缕のI，処贯

程度は、図 1 のよう I. 病状の観察

に処置を必要とする症状の看講

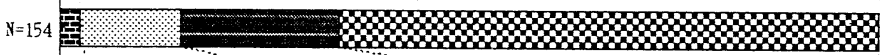

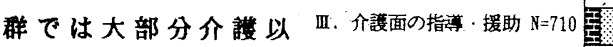

上が $85.1 \%$ 、病状の

覞察と定状の看鿁を

必要とする群、介丧 $v$. 生活指索

面の指導・援助を必要とする群では 60

〜 70\%、リハビリを必要とする群では

図1.ニーズ領域別にみた

$49.6 \%$ であっ。生活指導を必要とする群

日常生活の介謱の程度

ほとんど介讙は不要

では、ほとんど不要と一部介護が $72.9 \%$ ほっった。表 3 .ニーズ領域別にみた介淁上の困奞の出現率

次にニース領域别に介講上の困難ありとした者 の出現朿を示したものが表 3 である。処置を必要 とする群では日常生活行為の項目全てが30\%以上 の出現束で 11 項目中 8 項目は $60 \%$ 以上で、家庭生 活遂行上の困嚾出現亳も高い。だが医㙩確保の側 面は比較的低かつた。病状の钼察と症状の看荽を 必要とする群では、日常生活行為において $60 \%$ 以 上の困奞出現事は処置を必要とする群に比して少 ないが、医撩確保で $30 \%$ 以上の出現率が認められ た。介護面の指導・援助を必要とする群では日常 生活行為において前述の 2 群の中間的な困㬦の出 見事であるが、家庭生活遂行においてやや高かっ た。また、リハビリを必要とする群では日常生活 行為のうちADLに関する項目の困難出現事は高 いが会話や意志の伝達では低かつた。しかし医療 礁保面では $30 \%$ 以上の項目が認められた。生活指 導を必要とする群では、 $30 \%$ 以上の困難率を示す ものはなかった。

\section{結 敦}

1. 訪問開始時の主な二ーズ領域は「病状の覞察

と症状の看淁」「介棘面の指導・援助」「リハビ リ」のニースが多く合計 $86.4 \%$ で、「処置」「生 活指覓」は $10 \%$ 未满と少なかった。

2. 处置を必要とする群に日常生活で全面的介謱 の者が、生活指導にはほとんど介護不要の者が最 注1) 数字はNに刘する比事

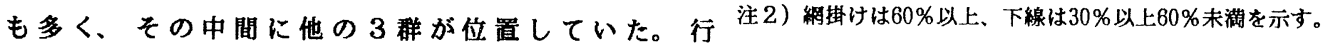

政として行なう訪問看謱では「病状の钼察と症状の看淁」「介謱面の指尊・援助」「リハビリ」 のニース項域を中心に、対象者の健康障害の幅の広いことが示唆された。

3. 処置を必要とする群では日常生活行為面の介謱困難出現事が最も高く、次いで介淁面の指導 ・援助、定状の知察と病状の看護、リハビリの順で、日常生活介缕の程度の重い群ほど困難の出 現率が高い傾向にあったが、医撩確保や家庭生活遂行面の困難ではリハビリ、病状の觀察と定状 の看绕、介缕面の指導・援助を必要とする群に出現事が高い傾向が認められた。 